\title{
Fostering Well-Being over the Radio? An Empirical Study Investigating the Effects of an Audio Podcast-Based Intervention Program on Student Teachers' Well-Being
}

\section{Benjamin Dreer ${ }^{1}$ (D)}

Received: 24 April 2020 / Accepted: 1 December 2020 / Published online: 14 January 2021

(C) The Author(s) 2021

\begin{abstract}
Student teachers' abilities to positively influence their own well-being are an important resource not only for their academic success at university but also for their future impact as educators in schools. Thus, universities should assume responsibility for educating student teachers on how to reflect on and influence their personal well-being. In this paper, an empirical study is presented that investigates the effects of an audio podcast-based intervention on student teachers' well-being. The online course was developed with the aim of fostering both the general and job-related well-being of student teachers during a 15-week pedagogical field experience. The course comprises a series of nine narrated audio podcast episodes and administers three positive psychological interventions: gratitude, kindness, and savouring. To investigate the effectiveness of the course, a quasi-experimental design was used. Life satisfaction, happiness, teacher engagement, job satisfaction, and emotional exhaustion were measured using online questionnaires at four intervals over a 15 -week period. The sample consisted of 117 German student teachers, of which 82 participated in the intervention and 35 in the control condition. Results suggest small but statistically significant gains in mean life satisfaction and happiness scores of the participants in the intervention group. Furthermore, significant gains in emotional exhaustion in the control group were not present in the intervention condition, suggesting that the course provides a buffer to emotional exhaustion. Against the expectations, indicators of job-related well-being (i.e. teacher engagement, job satisfaction) did not significantly change over time in either group. The relevance and limitations of these findings are discussed.
\end{abstract}

Keywords Student teachers $\cdot$ Well-being $\cdot$ Podcast $\cdot$ Positive psychological intervention

Benjamin Dreer

benjamin.dreer@uni-erfurt.de; https://orcid.org/0000-0001-5104-9910

1 Erfurt School of Education, University of Erfurt, Erfurt, Germany 


\section{Background}

Student teachers (i.e., university students preparing to become school teachers) form a community that is influenced by two reference groups (Dreer, 2020b). First, student teachers are university students who aim to thrive academically and succeed in typical study-related tasks, such as understanding how their university operates, familiarizing themselves with work tasks and the methods of academic staff, and finding a peergroup and peer support among fellow students (Awang et al., 2014; Goodday et al., 2019). Second, student teachers are future teachers who aim to succeed in typical occupation-related tasks, such as understanding how schools operate from a professional standpoint, familiarizing themselves with work tasks and the methods of educational practitioners (e.g. classroom management), test themselves in various professional roles of teachers, and finding support in communities of practise (Dreer, 2020b). Thus, the successful development of a professional self and the necessary competences for teaching demands not only integration into the academic community at university, but also the identification as a teacher and the integration into communities of practise. Furthermore, ongoing reflection and integration of academic and practical learning is required in both contexts.

Ideally, in teacher education, both of these "worlds" would be interconnected and there would be a fruitful discourse between the two "worlds" that would provide a synchronized learning and development environment for the student teachers. However, in reality, several challenges exist for student teachers in navigating between acquiring scientific knowledge and academic reasoning on one hand and successfully engaging in dynamic practical experiences and trials at schools on the other (Smith \& Avetisian, 2011). These challenges can result in demanding conditions that threaten individual well-being and satisfaction, especially during field experiences in teacher education (Kokkinos \& Stavropoulos, 2014; Mansfield et al., 2016; White \& Cornu, 2002).

\section{Student Well-Being}

The well-being of university students (i.e., life satisfaction and positive and negative affect) is highly relevant, as it enables them to successfully cope with common stressors in student life (e.g. demands in academic, financial and social domains), and to work productively and to contribute positively to the student community (Goodday et al., 2019; Lyubomirsky et al., 2005a; Schoeps et al., 2019; Sharp \& Theiler, 2018; Wilcox \& Nordstokke, 2019). It has been shown that the well-being of university students is linked to several beneficial factors and outcomes, such as higher self-control, endorsement of mastery-approach goals, better grades, academic satisfaction and performance, lower procrastination, and a less likely adoption of a fixed mindset (e.g. Howell, 2009; Pluut et al., 2015).

University students' well-being is dependent on several personal and environmental factors. For example, high demands, low control, and low peer support appear to exert a negative impact on satisfaction and well-being (Chambel \& Curral, 2005). Conversely, students' sense of belonging to a student peer group and identification with the university are positively associated with well-being, life satisfaction, and academic performance (Awang et al., 2014; Goodday et al., 2019). 
These findings raise important questions about the role of universities as a positive influence on the well-being of students (Schoeps et al., 2019). Based on empirical data, several suggestions have been made in this regard. For example, universities can engage in enhancing student satisfaction (Cotton et al., 2002), improving curriculum design (Field et al., 2015), realising evaluation and fair assessment (Howell \& Buro, 2015), providing tailored student services and support, and fostering student society activities (Baik et al., 2019). Moreover, universities can offer programs, courses, and learning environments that provide positive experiences (Stanton et al., 2016) and educate students on how to reflect and influence their personal well-being. This might involve learning how to organize social support or learning to be present or self-kind (Stallman et al., 2018). Interventions from positive psychology have been shown to be a valuable resource for achieving these objectives (Howell \& Passmore, 2019). In addition, technology can play an important role in delivering relevant content aimed at improving students' well-being; most of this content is not part of standard curricula. Studies confirm that the well-being of university students can be successfully addressed by smartphone apps (Bendtsen et al., 2020) and text messaging (Thomas \& Bendtsen, 2019).

\section{Student Teacher Well-Being}

The well-being of future teachers must be regarded as an important cornerstone for the health of school communities and school systems around the globe (McCallum \& Price, 2016; Seligman \& Adler, 2019; Viac \& Fraser, 2020). According to Viac and Fraser (2020), teacher well-being can be defined as "teachers' responses to the cognitive, emotional, health and social conditions pertaining to their work and their profession" (p. 18). In recent years, the relevance of teacher well-being has been discussed more frequently and more emphatically. It is portrayed as a central aspect of teachers' effectiveness and, therefore, as a driver of functional and effective schools and school systems (Cherkowski \& Walker, 2018; McCallum \& Price, 2010, 2016; McCullough, 2015; Seligman \& Adler, 2019). Research findings show, for example, that healthy teachers are more likely to inspire their students and spark their interest and motivation to engage in school subjects (Frenzel et al., 2009; Keller et al., 2014). Moreover, teachers with high job satisfaction perform better (Caprara et al., 2006; Judge et al., 2001) and highly engaged teachers appear to positively influence student engagement (Cardwell, 2011). The positive emotions of teachers have been linked to the use of more effective teaching methods (Moè et al., 2010) and to the learning success of their students (Sutton \& Wheatley, 2003). In addition, teacher well-being appears to be a relevant factor for the implementation of positive education, which has been described as a valuable resource for preparing younger generations for emerging societal challenges (McCallum \& Price, 2016; Seligman \& Adler, 2019; Slemp et al., 2017; Waters \& Loton, 2019).

Despite its suggested importance, there are only a handful of studies that investigate the effects of intervention programs that are aimed at fostering teacher well-being. For example, Chan $(2010,2013)$ was able to show that positive psychological interventions aimed at fostering teachers' gratitude had a positive impact on the subjective well-being of teachers in China. McCullough (2015) successfully improved the well-being of elementary school teachers by applying a strengths-based intervention from positive 
psychology. Rahm and Heise (2019) showed that a mix of certain positive activities embedded in an educational program can be beneficial for teachers' well-being. Dreer (2020a) has reported that teacher well-being can be fostered by an e-mail-based intervention comprised of a variety of positive activities.

While these approaches exclusively target in-service teachers, it is argued that there is no better starting point for developing and fostering the well-being competencies of teachers than in initial teacher education (Acton \& Glasgow, 2015; Briscoe, 2019; Byrne et al., 2015). Due to their high potential for learning (Hammerness et al., 2005; Zeichner, 2010) and extended workloads and demands (Chaplain, 2008; Gardner, 2011; Jantowski \& Ebert, 2014; Kokkinos \& Stavropoulos, 2014; Schüle et al., 2017), field experiences at schools during initial teacher education appear to be an appropriate environment for the application of positive psychological support for student teachers. Educating student teachers on how to positively influence their jobrelated well-being can be regarded as an important aspect of job preparation. However, empirical evidence on approaches for fostering the well-being of student teachers during practical phases is scarce. There are hints that being mentored by experienced practitioners during field experiences can positively influence student teachers' wellbeing, given a proper mentor-mentee relationship (Hollweck, 2019; Kutsyuruba et al., 2019; Squires, 2019). In addition, psychological need-fulfilment of student teachers during practical phases appears to be connected to certain quality indicators, such as learner satisfaction (Dreer, 2020b).

Programs fostering the resilience of future teachers were found to have potential benefits for the well-being of student teachers in the practical phases (Le Cornu, 2009; Mansfield et al., 2016). Supervision provided by university lecturers via E-Mail has been suggested to help reduce stress during field experiences (White \& Cornu, 2002). Ultimately, it appears that the potential of positive psychological interventions, particularly those found to be effective in increasing university students' and in-service teachers' well-being, has not yet been studied in the context of the well-being of student teachers in practical phases of teacher education.

\section{Podcast Intervention Program}

From the prior appraisal, three major insights emerge. First, as well-being appears to be linked to academic and practical performance, higher rates of student teacher wellbeing can be regarded as a contributing factor to improved preparation of new teachers towards the challenges of the teaching profession. Hence, universities should support student teacher well-being with, for example, dedicated courses. Second, programs and courses educating student teachers in ways of fostering and reflecting on their wellbeing could be helpful, especially alongside educational field experiences. Third, for the purpose of educating student teachers and providing positive experiences regarding the self-regulation of their personal well-being, positive psychological interventions have been shown to be effective with students and schoolteachers. These insights inspired the development of an online course for student teachers in the practical phases of their teacher education. The initiative is based upon the positive-activity model (Lyubomirsky \& Layous, 2013), which proposes that positive activities have a beneficial influence on positive emotions, thoughts and behaviours, as well as the 
fulfilment of basic psychological needs; this, in turn, leads to an increase in well-being. The goals, structure, elements, and workflow of the course are described in the following sections.

\section{Goals and Structure}

The goal of the course Positivity for Student Teachers is to foster student teachers' wellbeing during a long-term field experience in their initial teacher education. By means of familiarizing the participants with positive psychology and motivating their regular engagement in job-related positive psychological interventions, the course aims to help the students develop a sensitivity for the topic and a validated tool kit for their personal use.

The course is divided into three phases (see Table 1). Phase 1 is the 6-week phase of knowledge acquisition, where participants are provided with knowledge about the origins and effects of typical challenges in the teaching profession. During this phase, knowledge is provided on the concerns, scientific basis and prominent findings of positive psychology, especially regarding positive psychological interventions. Phase 2 is the 6-week phase of practising, where participants are familiarized with three positive psychological interventions. They are encouraged to habitually engage in these interventions for a 2 -week period each. Phase 3 is the 4-week phase of reflection, where student teachers are supported in reflecting on the possible effects of participating in the course and especially of engaging in the positive activities with regard to their general and job-related well-being.

Table 1 Workflow of the online course

\begin{tabular}{|c|c|c|}
\hline Time periods & Phase (Number of episodes) & Elements and tasks \\
\hline \multirow{2}{*}{$\begin{array}{l}\text { Until the end of the first } \\
\text { week of the practical } \\
\text { phase }\end{array}$} & \multirow{6}{*}{$\begin{array}{l}\text { Phase 1: Acquisition of } \\
\text { knowledge (4) }\end{array}$} & • Listen to episode 1 "Welcome" \\
\hline & & - Record data at check-in 1 \\
\hline Week 2-3 & & - Listen to episode 2 "Demands of Teaching" \\
\hline Week 4-5 & & $\begin{array}{l}\text { - Listen to episode } 3 \text { "Basics of Positive } \\
\text { Psychology" }\end{array}$ \\
\hline \multirow[t]{2}{*}{ Week 6-7 } & & $\begin{array}{l}\text { - Listen to episode } 4 \text { "Positive Psychological } \\
\text { Interventions" }\end{array}$ \\
\hline & & - Record data at check-in 2 \\
\hline \multirow[t]{2}{*}{ Week 8-9 } & \multirow[t]{4}{*}{ Phase 2: Practising (3) } & - Listen to episode 5 "Practise Gratitude" \\
\hline & & - Record data at check-in 3 \\
\hline \multirow[t]{2}{*}{ Week 10-11 } & & - Listen to episode 6 "Practice Kindness" \\
\hline & & - Record data at check-in 4 \\
\hline \multirow[t]{2}{*}{ Week $12-13$} & & - Listen to episode 7 "Practice Savouring" \\
\hline & & - Record data at check-in 5 \\
\hline \multirow[t]{2}{*}{ Week $14-15$} & \multirow{4}{*}{$\begin{array}{l}\text { Phase } 3 \text { : Reflection } \\
\qquad(2+2 \text { bonus episodes })\end{array}$} & - Listen to episode 8 "Reflection" \\
\hline & & - Evaluate personal development graph \\
\hline \multirow{2}{*}{$\begin{array}{l}\text { Until end of the practical } \\
\text { phase }\end{array}$} & & - Listen to episode 9 "The End" \\
\hline & & - Listen to bonus episodes \\
\hline
\end{tabular}




\section{Elements and Workflow}

As student teachers have different time schedules and are rarely present on campus when in practical phases at schools, the program is offering flexibility through the use of digital communication. In general, technology is becoming increasingly important for addressing the well-being of communities (Wallace \& Vincent, 2017). It has been shown that positive psychological interventions can be successfully delivered online (Bolier \& Abello, 2014). The course presented here comprises four elements: a learning platform, an audio podcast, five successive online check-ins, and a personal development graph.

\section{Learning Platform and Audio Podcast}

The learning platform Moodle is used as the hub for course communication and the provision of learning materials. Moodle helps to organize course contents into a comprehensible structure and to present the contents stepwise. Apart from the major course elements, additional course material (e.g. texts, videos, and tests) are provided via the platform.

An audio podcast constitutes the core element of the course. The format was chosen because of its high flexibility and portability and its great popularity amongst the target group (Popovaa \& Edirisingha, 2010). Furthermore, podcasts appear to be effective in knowledge transition and for inspiring engagement (McKinney et al., 2009). Audio podcasts are a promising tool for bridging the gap between academic learning at universities and practical learning in schools. Student teachers are able to listen during their daily commutes to school.

In total, nine episodes with a maximum length of $20 \mathrm{~min}$ were produced by means of writing, recoding, and scoring (see Table 1). A story-telling style was chosen in order to provide an engaging experience (Allen, 2019). To gain the audience's attention, every episode starts with an opener, which could be a short story, anecdote, or snippet from a song or movie. The contents of the episodes are presented in a way that ties in personal experiences and triggers reflective thinking. The spoken contents are accompanied by ambient music that supports the message of each episode. In addition to the regular episodes, two bonus episodes were produced containing interviews with scientists discussing their findings on teacher well-being and providing suggestions for future teachers. It is intended that more bonus episodes will be added over time.

The first four episodes (Phase 1: knowledge acquisition) focus on presenting scientific knowledge about teacher well-being and positive psychology. Participants are encouraged to conduct observations and interviews at their school, seeking out positive role models in stress prevention and coping, and learning from their insights.

Episodes five to seven (Phase 2: practising) focus on introducing and explaining three interventions (one every 2 weeks) from positive psychology. Participants are encouraged to engage in the positive activities regularly within their teaching placement context. Amongst the interventions were "three-goodthings" (participants were instructed to record three good things that they encountered during their day at school; based on Seligman et al., 2005), 
"random acts of kindness" (participants were instructed to preform three random acts of kindness every working day towards school staff or students; based on Lyubomirsky et al., 2005b), and "mindful photography" (participants were instructed to take two mindful photographs of subjects, e.g. people, buildings, or items, representing positive memories about their practical phase; based on Smith et al., 2014). One reason for choosing these interventions is the substantial amount of empirical evidence with regard to their positive effects on well-being. Another reason is that the interventions are easily adaptable to the teaching placement context; however, at the same time they are not too invasive with regard to everyday school life and the limited freedom of action of student teachers. For each intervention, a range of minor adaptions are suggested in order to allow for personal choice and to optimize the person-activity fit (Schueller, 2014).

In the last two episodes (Phase 3: reflection), participants were encouraged to evaluate their experiences from the prior course phases. For that purpose, participants were provided with a personal development graph (see below).

\section{Check-Ins and Development Graph}

At certain intervals in the course (see Table 1), participants were prompted to fill out online questionnaires recording their well-being related data. Following the fifth check-in, a personal development graph was prepared and sent to every participant. The graph plots the development of student teachers' well-being data during the field experience and highlights the three periods where participants engaged in the positive interventions. Podcast episode eight provides guidance for interpreting the personal development graph and impulses for reflecting the success of the activities on that basis. Participants were encouraged to communicate their insights with their mentors at school and with fellow students at university.

\section{Research Question and Hypotheses}

The present study addresses the following research question: To what extent does the presented audio podcast-based intervention for student teachers exert effects on general well-being (i.e. life satisfaction, happiness) and job-related well-being (i.e. job satisfaction, teacher engagement, and emotional exhaustion) of student teachers?

Based on prior research on positive psychological interventions, small to moderate effects are expected with regard to the following two hypotheses:

- H1. The participants assigned to the intervention group will show a significantly stronger increase in subjective well-being compared with those assigned to the control group.

- H2. The participants assigned to the intervention group will show a significantly stronger increase in job-related well-being compared with those assigned to the control group. 


\section{Research Method}

\section{Design}

In order to answer the research question and to test the two hypotheses, a pseudo experiment was conducted (see Table 2). The intervention was implemented within an existing course structure accompanying a 15-week pedagogical field experience at the end of the Master of Education studies at the University of Erfurt, Germany. During their internship in schools, all students are obliged to participate in mandatory courses at the university. As part of the existing procedure, student teachers take four oncampus courses on various (non-well-being) topics (e.g. lesson planning, school development). The control group size represents the size of one regular on-campus course. Well-being data were collected in paper-pencil-format during the mandatory sessions.

Participants in the intervention condition registered voluntarily for the online course and were allowed to substitute one of the on-campus courses with the online audio podcast course. However, opting for the podcast course did not free student teachers from participating in three on-campus courses. Hence, participating in the intervention did not constitute a less demanding alternative in order to fulfil the formal demands. The podcast course with its focus on job-related well-being was introduced to the student teachers during the central kick-off meeting for the field experience. Student teachers had a 2-week period to consider whether to participate and then to register via e-mail. Data on the intervention group participants were collected online as part of the course proceedings.

\section{Participants}

The entire group of participants $(N=117)$ consisted of student teachers in their last year of Master of Education studies at the University of Erfurt. The sample contained 96 women $(82 \%)$ and 21 men $(18 \%)$. The mean age was 25.5 years $(\mathrm{SD}=3.39$; $\operatorname{Min}=23$; Max $=41)$. The participants included teachers of both primary $(77 \%)$ and secondary (23\%) education school types.

Of the total sample, 82 student teachers participated in the intervention group and 35 in the control group. The groups did not differ regarding their mean age $(\mathrm{F}(1$, $116)=.11, p=.69)$, and gender ratio $\left(\chi^{2}(117)=3.11, p=.53\right)$. Gender and schooltype ratios were representative of the population of student teachers at the University of Erfurt. No missing data occurred.

Table 2 Design of the study

\begin{tabular}{|c|c|c|c|c|c|}
\hline Time and measurement intervals & 6 weeks & 6 weeks & $\mathrm{t} 3$ & 4 weeks & $\mathrm{t} 4$ \\
\hline \multirow[t]{2}{*}{ Intervention condition } & \multicolumn{5}{|c|}{ Online podcast course "Positivity for Student Teachers" } \\
\hline & Phase 1: Knowledge & Phase 2: Practise & $\mathrm{Ph}$ & 3: Reflec & \\
\hline \multirow[t]{2}{*}{ Control condition } & \multicolumn{5}{|c|}{ On-campus courses (various topics, e.g. school development) } \\
\hline & Course proceedings & Course proceedings & $\mathrm{Co}$ & se proceed & \\
\hline
\end{tabular}




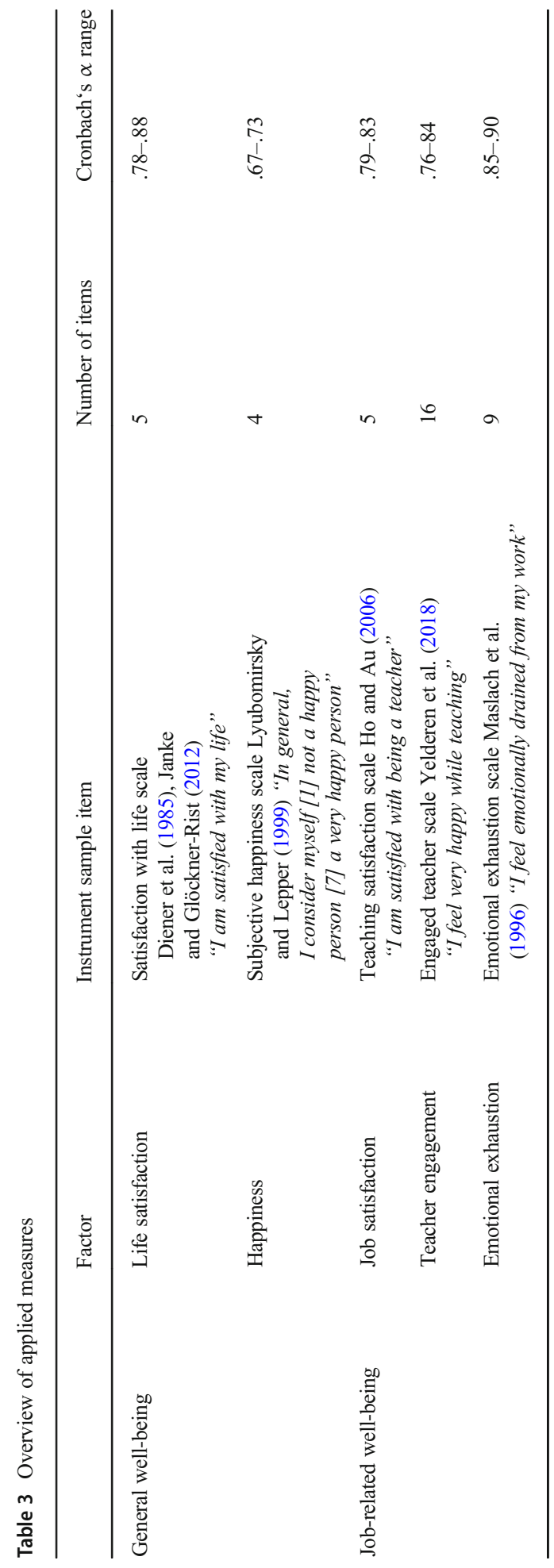




\section{Instruments}

In order to answer the research question, two groups of factor sets and respective measures for each set were identified and applied (see Table 3). Measuring general well-being, life satisfaction, and happiness were assessed using the German version of the Satisfaction with Life Scale (Janke \& Glöckner-Rist, 2012) and the Subjective Happiness Scale (Lyubomirsky \& Lepper, 1999); the latter was translated into German. Job-related well-being was assessed using scales measuring job satisfaction (Ho \& $\mathrm{Au}, 2006$ ), teacher engagement (Yelderen et al., 2018), and emotional exhaustion (Maslach et al., 1996). Items were translated into German and adapted to the situation of student teachers in-field experiences (e.g. "I am satisfied with my job" adapted to "I am satisfied with my job aspiration").

All items, except for the items of the happiness scale ( 7 point), were rated on a fivepoint scale ranging from 1 - "does not apply" to 5 - "fully applies."

\section{Data Analysis}

Preliminary analyses included tests for internal consistency. The results are reported in Table 2 . Furthermore, descriptive data (Table 3) and intercorrelations (Table 4) were computed and assessed. As the hypotheses were tested using analyses of variance and t-tests, the preliminary analyses also tested for the approximate normal distribution and sphericity.

\section{Results}

\section{Descriptive Findings}

Table 2 provides an overview of the means and the standard deviations for all factors, intervals, and groups. Means at the first interval for all applied measures were

Table 4 Descriptive data for all measures at all four intervals

\begin{tabular}{|c|c|c|c|c|c|c|c|c|}
\hline & \multicolumn{2}{|l|}{$\mathrm{T} 1$} & \multicolumn{2}{|l|}{$\mathrm{T} 2$} & \multicolumn{2}{|l|}{$\mathrm{T} 3$} & \multicolumn{2}{|l|}{$\mathrm{T} 4$} \\
\hline & $\begin{array}{l}\text { IG } \\
\mathrm{M} \\
\text { (SD) }\end{array}$ & $\begin{array}{l}\mathrm{CG} \\
\mathrm{M} \\
(\mathrm{SD})\end{array}$ & $\begin{array}{l}\text { IG } \\
\text { M } \\
\text { (SD) }\end{array}$ & $\begin{array}{l}\text { CG } \\
\mathrm{M} \\
(\mathrm{SD})\end{array}$ & $\begin{array}{l}\text { IG } \\
\mathrm{M} \\
(\mathrm{SD})\end{array}$ & $\begin{array}{l}\text { CG } \\
\mathrm{M} \\
(\mathrm{SD})\end{array}$ & $\begin{array}{l}\text { IG } \\
\text { M } \\
\text { (SD) }\end{array}$ & $\begin{array}{l}\mathrm{CG} \\
\mathrm{M} \\
(\mathrm{SD})\end{array}$ \\
\hline Life satisfaction & $\begin{array}{c}3.80 \\
(0.51)\end{array}$ & $\begin{array}{c}3.78 \\
(0.52)\end{array}$ & $\begin{array}{c}3.74 \\
(0.54)\end{array}$ & $\begin{array}{c}3.71 \\
(0.54)\end{array}$ & $\begin{array}{c}4.02 \\
(0.51)\end{array}$ & $\begin{array}{c}3.69 \\
(0.74)\end{array}$ & $\begin{array}{c}4.05 \\
(0.58)\end{array}$ & $\begin{array}{c}3.69 \\
(0.75)\end{array}$ \\
\hline Happiness & $\begin{array}{c}5.25 \\
(0.89)\end{array}$ & $\begin{array}{c}5.29 \\
(0.88)\end{array}$ & $\begin{array}{c}5.18 \\
(0.78)\end{array}$ & $\begin{array}{c}5.18 \\
(1.11)\end{array}$ & $\begin{array}{c}5.44 \\
(0.79)\end{array}$ & $\begin{array}{c}5.21 \\
(1.18)\end{array}$ & $\begin{array}{c}5.50 \\
(0.79)\end{array}$ & $\begin{array}{c}5.25 \\
(0.99)\end{array}$ \\
\hline Job satisfaction & $\begin{array}{c}3.70 \\
(0.60)\end{array}$ & $\begin{array}{c}3.75 \\
(0.66)\end{array}$ & $\begin{array}{c}3.71 \\
(0.61)\end{array}$ & $\begin{array}{c}3.78 \\
(0.62)\end{array}$ & $\begin{array}{c}3.76 \\
(0.55)\end{array}$ & $\begin{array}{c}3.71 \\
(0.69)\end{array}$ & $\begin{array}{c}3.75 \\
(0.57)\end{array}$ & $\begin{array}{c}3.72 \\
(0.67)\end{array}$ \\
\hline Teacher engagement & $\begin{array}{c}4.37 \\
(0.28)\end{array}$ & $\begin{array}{c}4.32 \\
(0.30)\end{array}$ & $\begin{array}{c}4.39 \\
(0.28)\end{array}$ & $\begin{array}{c}4.33 \\
(0.32)\end{array}$ & $\begin{array}{c}4.39 \\
(0.39)\end{array}$ & $\begin{array}{c}4.28 \\
(0.42)\end{array}$ & $\begin{array}{c}4.41 \\
(0.37)\end{array}$ & $\begin{array}{c}4.29 \\
(0.39)\end{array}$ \\
\hline Emotional exhaustion & $\begin{array}{c}1.82 \\
(0.59)\end{array}$ & $\begin{array}{c}1.78 \\
(0.50)\end{array}$ & $\begin{array}{c}2.07 \\
(0.60)\end{array}$ & $\begin{array}{c}2.08 \\
(0.47)\end{array}$ & $\begin{array}{c}1.96 \\
(0.69)\end{array}$ & $\begin{array}{c}2.27 \\
(0.74)\end{array}$ & $\begin{array}{c}2.01 \\
(0.71)\end{array}$ & $\begin{array}{c}2.17 \\
(0.73)\end{array}$ \\
\hline
\end{tabular}


consistent with previously published population-based norms from the sources listed in Table 3.

While the means for life satisfaction and happiness increased over time for the intervention condition, they remained relatively constant for the control condition. Means for job satisfaction and teacher engagement remained relatively constant over time in both groups. The means of emotional exhaustion tended to increase over time, however, with apparent differences for intervention and control conditions from interval $\mathrm{t} 3$ onwards.

Pearson correlations revealed interrelations between the measured factors (see Table 5). The effect sizes and directions of the relationships appear plausible. Happier student teachers also reported more satisfaction with life. Individuals who were more satisfied with their choice of occupation reported higher rates of engagement and lower rates of emotional exhaustion. The correlations amongst the factors within the factor sets general well-being (1 and 2) and job-related wellbeing (3-5) were statistically significant and of small to medium degrees.

\section{Main Results}

In order to test the hypotheses, a repeated measures MANOVA was conducted. Results indicate a statistically significant effect of time $(\mathrm{F}(5,116)=3.54, p=.003)$, however no significant effect of group $(\mathrm{F}(5,116)=2.90, p=.021)$ or group and time $\times$ group interaction $(\mathrm{F}(5,116)=2.00, p=.092)$. As part of the procedure, post hoc univariate analyses were performed to specify the effects.

\section{General Well-Being}

In order to test the assumption that the participants assigned to the intervention group show a significantly stronger increase in general well-being compared with those assigned to the control group (H1), univariate post hoc tests of the measures of life satisfaction and happiness were evaluated.

Post hoc tests for life satisfaction pointed to a statistically significant effect of group $\times$ time interaction $(\mathrm{F}(1,116)=5.34, p=.002)$. Follow up tests revealed significant differences between groups at intervals $\mathrm{t} 3(\mathrm{t}=2.8, p<.005, \mathrm{~d}=.57)$ and $t 4(t=2.9, p<.005, d=.57)$. Consequently, life satisfaction increased in the

Table 5 Pearson correlations amongst factors at the first interval

\begin{tabular}{lccccc}
\hline & 1 & 2 & 3 & 4 & 5 \\
\hline 1 Life satisfaction & 1 & $.48^{* *}$ & $.39 * *$ & $.39 * *$ & $-.36^{* * *}$ \\
2 Happiness & $.48^{* *}$ & 1 & $.32^{* *}$ & .23 & $-.35^{*}$ \\
3 Job satisfaction & $.39 * *$ & $.32^{*}$ & 1 & $.44 * *$ & $-.60^{* *}$ \\
4 Teacher engagement & $.39 * *$ & .23 & $.44^{* *}$ & 1 & $-.33^{*}$ \\
5 Emotional exhaustion & $-.36^{* *}$ & $-.35^{*}$ & $-.60^{* *}$ & $-.33^{*}$ & 1 \\
\hline
\end{tabular}

$* * *$ Note: $p<.05 ; p<.01$ 
intervention group between $\mathrm{t} 2$ and $\mathrm{t} 3$, and this difference could still be observed at interval t4. Other significant differences were not found (Fig. 1).

Post hoc tests for happiness pointed to a statistically significant effect of group $\times$ time interaction $(\mathrm{F}(1,116)=7.15, p=.004)$. Follow up tests revealed significant differences between groups at intervals $\mathrm{t} 3(\mathrm{t}=2.9, p<.005, \mathrm{~d}=.25)$ and $\mathrm{t} 4(\mathrm{t}=2.8, \mathrm{p}$ $<.005, \mathrm{~d}=.30$ ). Thus, happiness increased in the intervention group between $\mathrm{t} 2$ and $\mathrm{t} 3$, and this difference could still be observed at interval $\mathrm{t} 4$. Other significant differences were not found (Fig. 2).

\section{Job-Related Well-Being}

In order to test the assumption that the participants assigned to the intervention group show a significantly stronger increase in job-related well-being compared with those assigned to the control group (H2), univariate post hoc tests of the measures of job satisfaction, teacher engagement, and emotional exhaustion were evaluated.

Post hoc tests for job satisfaction showed neither an effect of time $(F(1,116)=0.84$, $p=.36)$ nor a group $\times$ time interaction $(\mathrm{F}(4,116)=0.20, p=.66)$. Job satisfaction did not change in both groups over time (Fig. 3).

Post hoc tests for teacher engagement showed neither a significant effect of time $(\mathrm{F}(1,116)=0.25, p=.62)$ nor a group $\times$ time interaction $(\mathrm{F}(1,116)=0.52, p=.47)$. Teacher engagement did not change significantly in both groups over time (Fig. 4).

Post hoc tests for emotional exhaustion showed a significant effect of the group $\times$ time interaction $(\mathrm{F}(1,116)=4.16, p=.004)$. Follow up tests revealed a statistically significant group difference for interval $\mathrm{t} 3(\mathrm{t}=2.7, p<.005, \mathrm{~d}=.47)$. Emotional exhaustion increased in both the control and intervention groups

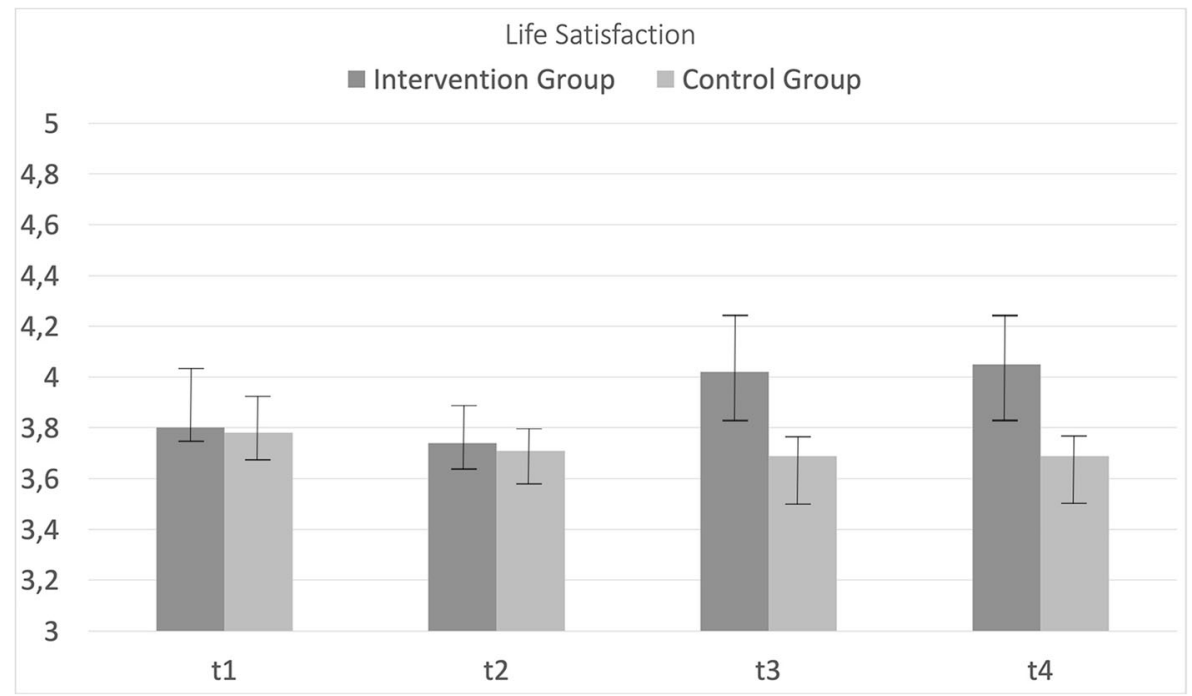

Fig. 1 Change in life satisfaction score for the intervention and control group over the four measurement intervals (95\% confidence intervals) 


\section{Happiness \\ - Intervention Group $\quad$ Control Group}

6

5,5

5

4,5

4

3,5

3

t1

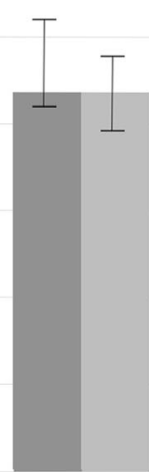

t2

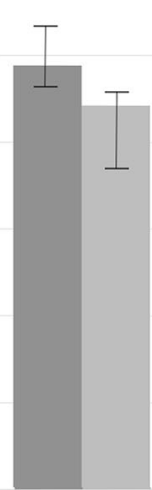

t3

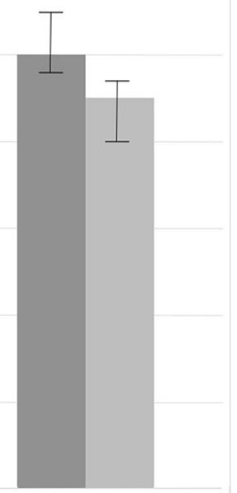

t4

Fig. 2 Change in happiness score for the intervention and control group over the four measurement intervals (95\% confidence intervals)

between $\mathrm{t} 1$ and $\mathrm{t} 2$, but no group differences were found. Between $\mathrm{t} 2$ and $\mathrm{t} 3$ emotional exhaustion further increased in the control condition, but no further increase was observed in the intervention condition (Fig. 5). At interval t4 the group difference in emotional exhaustion was apparent.

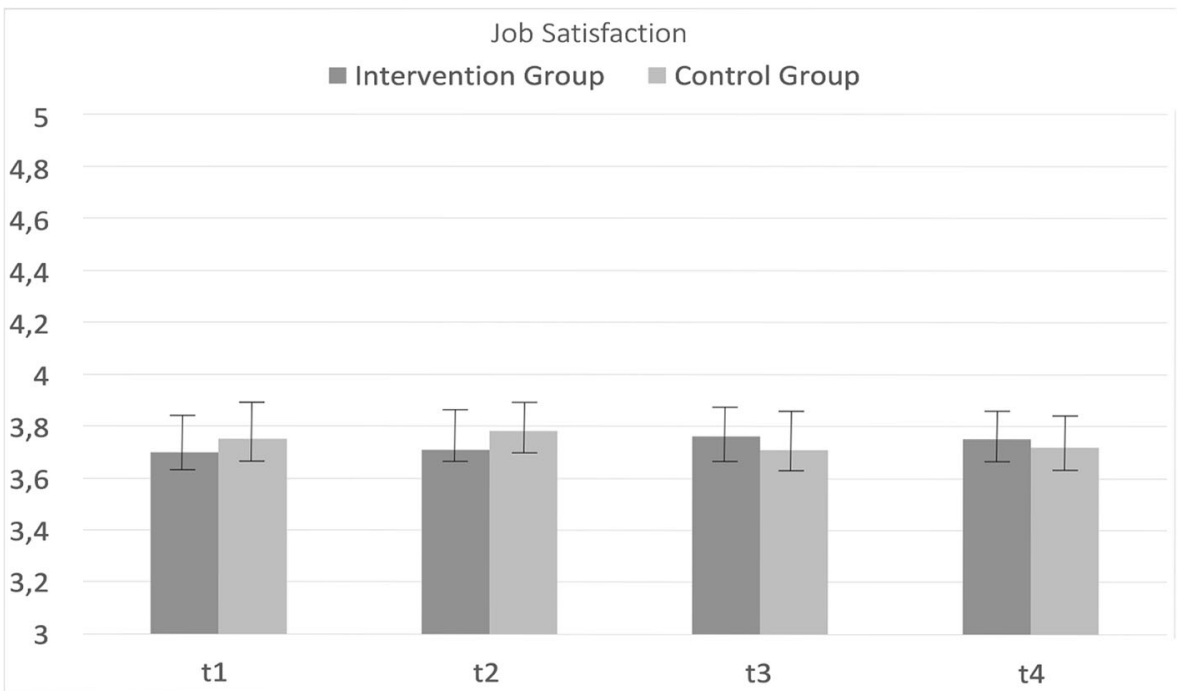

Fig. 3 Change in job satisfaction score for the intervention and control group over the four measurement intervals (95\% confidence intervals) 


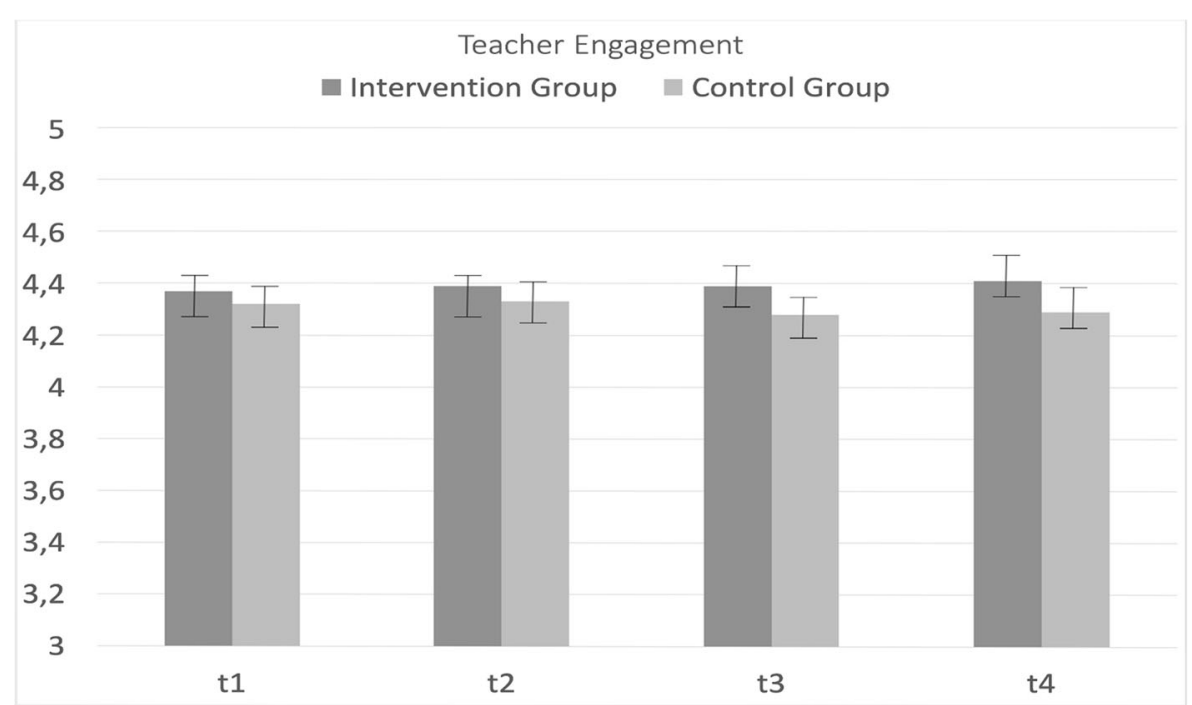

Fig. 4 Change in teacher engagement score for the intervention and control group over the four measurement intervals $(95 \%$ confidence intervals)

\section{Findings from the Course Evaluation}

After finishing the podcast course, participants were asked to voluntarily provide feedback regarding the usability of the course material, their use of this material,

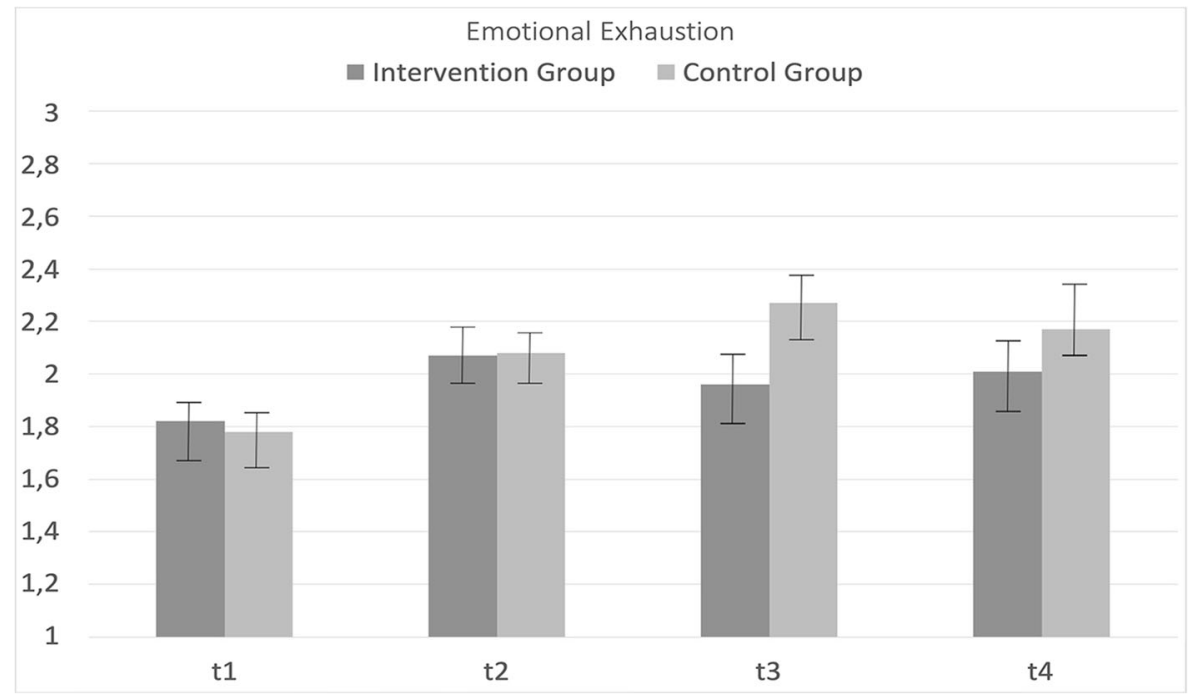

Fig. 5 Change in emotional exhaustion score for the intervention and control group over the four measurement intervals (95\% confidence intervals) 
and their impressions of the course format. From the initial 82 intervention participants 32 provided data. Due to self-selection, this data might be biased.

The majority of the 32 participants were satisfied with the workload of the course $(90 \%)$, the usability of the course elements $(87.5 \%)$, and the quality of the audio content (100\%). Participants expressed that the course was thoughtprovoking $(84 \%)$, pleasurable $(84 \%)$, and a good addition to their field experience (78\%). Student teachers listened to the audio podcasts at home, on their commutes, and during exercise. In open statements, participants highlighted their positive experiences with the course. For example, they felt "understood" and saw themselves confronted "with an interesting and important topic, which should be tackled more intensively in teacher education." Participants also acknowledged the check-ins reporting that "it was interesting and good fun to fill in the check-ins and see the graph at the end of the course." Finally, student teachers reported having been inspired by the course to engage in discussions with in-service teachers at schools and fellow students at university about well-being related topics. One participant concluded, "I would love to carry on listening to the podcast my entire work life."

As the control group did not participate in similar coursework, but instead took completely unrelated courses on different topics and without check-ins and development graphs, no such follow-up data was assessed in the control group.

\section{Discussion}

Student teachers are a special community among university students. They work towards a well-defined and, based on their own experiences as school students, a supposedly familiar profession. When developing a professional identity as future teachers, they are confronted with demands resulting from dialectical elements of teacher education. This can culminate in high individual demands, especially during field experiences in pre-service teacher education, which should prompt universities to address the well-being of student teacher communities by providing supportive measures. At the same time, to develop healthy schools and school systems, it is necessary for future teachers to be educated in ways to reflect and foster their personal and job-related well-being during initial teacher education. Against this background, the present paper has presented an innovative online course - Positivity for student teachers - and results suggest its effectiveness in promoting well-being in student teachers.

In agreement with hypothesis H1, life satisfaction and happiness increased for the intervention group, whereas changes in the control group were not observed. Notably, the increase appeared at the end of Phase 2, the phase in which the participants were instructed to regularly engage in positive activities. At the ends of Phases 1 (knowledge acquisition) and 3 (reflection), no further changes in life satisfaction and happiness were observed. Hence, the effects of the entire intervention can be traced back to the effects of the positive activities of gratitude, kindness, and savouring, which have previously been shown to be effective in this context (Bryant et al., 2005; Lomas et al., 2014; Smith et al., 2014). Effect sizes suggest small to medium effects of the interventions, and these effects persisted for 4 weeks after the interventions. This is in 
line with prior research on positive psychological interventions (Bolier et al., 2013). The present study extends this prior research, as it provides data to support the successful use of the audio podcast format for administering positive psychological interventions.

Against the expectations stated in hypothesis H2, job satisfaction and teacher engagement did not increase in the intervention group. This does not correspond to prior research, which showed that job satisfaction and teacher engagement could potentially benefit from positive psychological interventions (Dreer, 2020a). However, the cited study addressed in-service teachers with interventions that were tailored towards the teaching profession and incorporated interactions based on the professional roles of the teacher (e.g. communicating with colleagues or students' parents). As student teachers in practical phases often do not have the freedom and confidence to freely interact with school staff or parents, the present course incorporated interventions that were more self-directed and could be conducted without much personal positive interaction at school. Interventions that require more positive interaction at school might have the effect of increasing job satisfaction and engagement. Finding the right balance between triggering positive professional interactions and producing frustration by confronting student teachers with their professional limitations is a challenge that could be met with a redesign of the second phase of the course, implementing more "invasive" (other-oriented) positive interventions.

Alternatively, the intervention could be reframed as a general well-being intervention for university students, as it proved to be promising for fostering general life satisfaction and happiness in university students. For the dissemination of positive psychological research, the components learning platform, audio podcast, check-ins and development graph could be regarded as useful tools.

The results also showed that emotional exhaustion at first increased over time in both the control and intervention groups. There are some hints that this could be considered as a normal progression within a long-term field experience, as demands tend to increase over time (Jantowski \& Ebert, 2014; Schüle et al., 2017). The online course may have had the effect of buffering the student teachers from the negative effects of the practical phase on emotional exhaustion. Group differences were found at interval $\mathrm{t} 3$, after practising the interventions, and showed an increase in emotional exhaustion only for the control condition. However, further research is needed to test this buffer hypothesis.

Future research should also address the limitations of the present study. Shortcomings regarding the sample of student teachers must be addressed. First, these results were obtained from a rather small sample size and suggest that caution must be taken in interpreting the findings. In order to achieve a larger sample size, which would increase the power of the statistical analysis, it is planned to make the revised course available to student teachers at other German universities. Second, student teachers opted to participate in the course on a voluntary basis, and hence the intervention and control group composition was not balanced with respect to the study population. As a result, this could have biased the samples because, for example, student teachers with a high interest in the topic would be more likely to take part in the course. As a consequence, it is unclear from this analysis to what extent those student teachers who are less interested in the topic 
and might be less motivated to regularly engage in positive activities could benefit from the course. This question could be addressed using a randomized controlled trial and by evaluating a possible aptitude treatment interactions (Bracht, 1970). If this cannot be achieved, a future study should at least gather respective motivational data and included it as covariates in the analyses.

Another limitation of these results arises from the use of self-reported data, which are prone to biases and the inflation of correlations (Blume et al., 2010). Future studies could apply additional measures, such as methods of mobile experience sampling that are deemed to increase the accuracy of the data collection process and increase the ability to detect meaningful within-person variability (Carson et al., 2010). Likewise, the use of behavioural observations and biopsychological data could provide further insights (Gouasé et al., 2019). With a focus on student teacher communities, measurement could also incorporate community well-being measures (e.g., Atkinson et al., 2017; VanderWeele, 2019), which could be useful to assess community-related domains of well-being.

To conclude, on the basis of these results, it can be argued that the well-being of a community can be enhanced with specific tools from positive psychology. Furthermore, technology appears to be helpful in the distribution of content and tools into a dispersed community. However, lessons from this approach also highlight the necessity to continuously study and better understand the needs of the target community in order to tailor effective and efficient interventions that not only spark individual well-being but inspire the community members to interact and connect positively. Teacher education and research on teacher education could benefit from a community approach in many ways. The application of community well-being principals (Cloutier et al., 2019) are one example. Transferred to student teacher communities, the principles of purpose (What is the purpose and value of both fellow student and practice communities?), place (How can both the university and schools interconnect?; Which connections support the well-being and flourishing of the community members?; How can knowledge, experience, and emotion be transferred in multidirectional ways?), and relation (What makes the relationship of student teachers and experienced in-service teachers prosperous?; How can the well-being of both parties be affected positively?) provide a promising analytical perspective.

Authors' Contributions Not applicable.

Funding Open Access funding enabled and organized by Projekt DEAL..

\section{Compliance with Ethical Standards}

Conflict of Interest The authors declare that they have no conflict of interest.

Data Availability The dataset is not publicly available. Material (German language) can be made available on request.

Code Availability Not applicable. 
Open Access This article is licensed under a Creative Commons Attribution 4.0 International License, which permits use, sharing, adaptation, distribution and reproduction in any medium or format, as long as you give appropriate credit to the original author(s) and the source, provide a link to the Creative Commons licence, and indicate if changes were made. The images or other third party material in this article are included in the article's Creative Commons licence, unless indicated otherwise in a credit line to the material. If material is not included in the article's Creative Commons licence and your intended use is not permitted by statutory regulation or exceeds the permitted use, you will need to obtain permission directly from the copyright holder. To view a copy of this licence, visit http://creativecommons.org/licenses/by/4.0/.

\section{References}

Acton, R., \& Glasgow, P. (2015). Teacher wellbeing in neoliberal contexts: A review of the literature. Australian Journal of Teacher Education, 40(8), 6.

Allen, J. L. (2019). Teaching with narrative nonfiction podcasts. Journal of Educational Multimedia and Hypermedia, 28(2), 139-164.

Atkinson, S., Bagnall, A.-M., Corcoran, R., \& South, J. (2017). What is community wellbeing? Conceptual review. What Works Wellbeing Centre Community Wellbeing Evidence Programme (CWEP), available at http://whatworkswellbeing.org. Accessed 30 Nov 2020.

Awang, M. A., Kutty, F. M., \& Ahmad, A. R. (2014). Perceived social support and well being: First-year student experience in university. International Education Studies, 7(13), 261-270.

Baik, C., Larcombe, W., \& Brooker, A. (2019). How universities can enhance student mental wellbeing: The student perspective. Higher Education Research \& Development, 38(4), 674-687.

Bendtsen, M., Mussener, U., Linderoth, C., \& Thomas, K. (2020). A Mobile health intervention for mental health promotion among university students: Randomized controlled trial. JMIR mHealth and uHealth, 8(3), e17208. https://doi.org/10.2196/17208.

Blume, B. D., Ford, J. K., Baldwin, T. T., \& Huang, J. L. (2010). Transfer of training: A meta-analytic review. Journal of Management, 36(4), 1065-1105.

Bolier, L., \& Abello, A. M. (2014). Online positive psychological interventions: State of the art and future directions. In A. C. Parks \& S. M. Schueller (Eds.), The Wiley-Blackwell handbook of positive psychological interventions (pp. 286-309). Chichester: Wiley.

Bolier, L., Haverman, M., Westerhof, G. J., Riper, H., Smit, F., \& Bohlmeijer, E. (2013). Positive psychology interventions: A meta-analysis of randomized controlled studies. BMC Public Health, 13(1), 119.

Bracht, G. H. (1970). Experimental factors related to aptitude-treatment interactions. Review of Educational Research, 40(5), 627-645.

Briscoe, P. (2019). Virtual mentor partnerships between practising and preservice teachers: Helping to enhance professional growth and well-being. International Journal of Mentoring and Coaching in Education, 8(4), 235-254.

Bryant, F. B., Smart, C. M., \& King, S. P. (2005). Using the past to enhance the present: Boosting happiness through positive reminiscence. Journal of Happiness Studies, 6(3), 227-260.

Byrne, J., Shepherd, J., Dewhirst, S., Pickett, K., Speller, V., Roderick, P., Grace, M., \& Almond, P. (2015). Pre-service teacher training in health and well-being in England: The state of the nation. European Journal of Teacher Education, 38(2), 217-233.

Caprara, G. V., Barbaranelli, C., Steca, P., \& Malone, P. S. (2006). Teachers' self-efficacy beliefs as determinants of job satisfaction and students' academic achievement: A study at the school level. Journal of School Psychology, 44(6), 473-490.

Cardwell, M. E. (2011). Patterns of relationships between teacher engagement and student engagement. Education Doctoral, Paper 49, available at https://fisherpub.sjfc.edu/education_etd/49. Accessed 30 Nov 2020.

Carson, R. L., Weiss, H. M., \& Templin, T. J. (2010). Ecological momentary assessment: A research method for studying the daily lives of teachers. International Journal of Research and Method in Education, 33(2), 165-182.

Chambel, M. J., \& Curral, L. (2005). Stress in academic life: Work characteristics as predictors of student well-being and performance. Applied Psychology, 54(1), 135-147.

Chan, D. W. (2010). Gratitude, gratitude intervention and subjective well-being among Chinese school teachers in Hong Kong. Educational Psychology, 30(2), 139-153. 
Chan, D. W. (2013). Counting blessings versus misfortunes: Positive interventions and subjective well-being of Chinese school teachers in Hong Kong. Educational Psychology, 33(4), 504-519.

Chaplain, R. P. (2008). Stress and psychological distress among trainee secondary teachers in England. Educational Psychology, 28(2), 195-209.

Cherkowski, S., \& Walker, K. D. (2018). Teacher wellbeing: Noticing, nurturing, sustaining, and flourishing in schools. Burlington, ON: Word \& Deed Publishing.

Cloutier, S., Ehlenz, M. M., \& Afinowich, R. (2019). Cultivating community wellbeing: Guiding principles for research and practice. International Journal of Community Well-Being, 2(3), 277-299.

Cotton, S. J., Dollard, M. F., \& de Jonge, J. (2002). Stress and student job design: Satisfaction, well-being, and performance in university students. International Journal of Stress Management, 9(3), 147-162.

Diener, E., Emmons, R. A., Larsen, R. J., \& Griffin, S. (1985). The satisfaction with life scale. Journal of Personality Assessment, 49(1), 71-75.

Dreer, B. (2020a). Positive psychological interventions for teachers: A randomised placebo-controlled field experiment investigating the effects of workplace-related positive activities. International Journal of Applied Positive Psychology, 5, 77-97.

Dreer, B. (2020b). Towards a better understanding of psychological needs of student teachers during field experiences. European Journal of Teacher Education, 43(5), 676-694.

Field, R., Duffy, J., \& Huggins, A. (2015). Teaching independent learning skills in the first year: A positive psychology strategy for promoting law student well-being. Journal of Learning Design, 8(2), 1-10.

Frenzel, A. C., Goetz, T., Lüdtke, O., Pekrun, R., \& Sutton, R. E. (2009). Emotional transmission in the classroom: Exploring the relationship between teacher and student enjoyment. Journal of Educational Psychology, 101(3), 705-716.

Gardner, S. (2011). Stress among prospective teachers: A review of the literature. Australian Journal of Teacher Education, 36(1), 18-28.

Goodday, S. M., Rivera, D., Foran, H., King, N., Milanovic, M., Keown-Stoneman, C. D. G., Horrocks, J., Tetzlaff, E., Bowie, C. R., Pickett, W., Harkness, K., Saunders, K. E., Cunningham, S., McNevin, S., \& Duffy, A. (2019). U-Flourish university students well-being and academic success longitudinal study: A study protocol. BMJ Open, 9(8), e029854. https://doi.org/10.1136/bmjopen-2019-029854.

Gouasé, N., Braun, O., \& Raab, G. (2019). Multimethod stress evaluation: Effects of an intervention on teachers' health including self-report and biologically measurement. Poster presented at 33rd Annual Conference of the European Health Psychology Society, Dubrovnik, Croatia.

Hammerness, K., Darling-Hammond, L., Bransford, J., Berliner, D., Cochran-Smith, M., McDonald, M., et al. (2005). How teachers learn and develop. In L. Darling-Hammond \& J. Brandsford (Eds.), Preparing teachers for a changing world (pp. 358-390). San Francisco: Jossey-Bass.

Ho, C.-L., \& Au, W.-T. (2006). Teaching satisfaction scale: Measuring job satisfaction of teachers. Educational and Psychological Measurement, 66(1), 172-185.

Hollweck, T. (2019). "I love this stuff!": A Canadian case study of mentor-coach well-being. International Journal of Mentoring and Coaching in Education, 8(4), 325-344.

Howell, A. J. (2009). Flourishing: Achievement-related correlates of students' well-being. The Journal of Positive Psychology, 4(1), 1-13.

Howell, A. J., \& Buro, K. (2015). Measuring and predicting student well-being: Further evidence in support of the flourishing scale and the scale of positive and negative experiences. Social Indicators Research, 121(3), 903-915.

Howell, A. J., \& Passmore, H.-A. (2019). Acceptance and commitment training (ACT) as a positive psychological intervention: A systematic review and initial meta-analysis regarding ACT's role in wellbeing promotion among university students. Journal of Happiness Studies, 20(6), 1995-2010.

Janke, S., \& Glöckner-Rist, A. (2012). Deutsche version der satisfaction with life scale (SWLS). [German version of the satisfaction with life scale (SWLS)]. Zusammenstellung sozialwissenschaftlicher Items und Skalen (ZIS). https://doi.org/10.6102/zis147.

Jantowski, A., \& Ebert, S. (2014). Eine empirische Studie zu studentischen Belastungen. [An empirical study on student teachers' stress.]. In K. Kleinespel (Ed.), Ein Praxissemester in der Lehrerbildung [A long term field experience in initial teacher education] (pp. 76-96). Bad Heilbrunn: Klinkhardt.

Judge, T. A., Thoresen, C. J., Bono, J. E., \& Patton, G. K. (2001). The job satisfaction-job performance relationship: A qualitative and quantitative review. Psychological Bulletin, 127(3), 376-407.

Keller, M. M., Chang, M.-L., Becker, E. S., Goetz, T., \& Frenzel, A. C. (2014). Teachers' emotional experiences and exhaustion as predictors of emotional labor in the classroom: An experience sampling study. Frontiers in Psychology. https://doi.org/10.3389/fpsyg.2014.01442.

Kokkinos, C. M., \& Stavropoulos, G. (2014). Burning out during the practicum: The case of teacher trainees. Educational Psychology, 36(3), 1-21. 
Kutsyuruba, B., Godden, L., \& Bosica, J. (2019). The impact of mentoring on the Canadian early career teachers' well-being. International Journal of Mentoring and Coaching in Education, 8(4), 285-309.

Le Cornu, R. (2009). Building resilience in pre-service teachers. Teaching and Teacher Education, 25(5), 717-723.

Lomas, T., Froh, J. J., Emmons, R. A., Mishra, A., \& Bono, G. (2014). Gratitude interventions: A review and future agenda. In A. C. Parks \& S. M. Schueller (Eds.), The Wiley-Blackwell handbook of positive psychological interventions (pp. 3-19). Chichester: Wiley.

Lyubomirsky, S., \& Layous, K. (2013). How do simple positive activities increase well-being? Current Directions in Psychological Science, 22(1), 57-62.

Lyubomirsky, S., \& Lepper, H. (1999). A measure of subjective happiness: Preliminary reliability and construct validation. Social Indicators Research, 46(2), 137-155.

Lyubomirsky, S., King, L., \& Diener, E. (2005a). The benefits of frequent positive affect: Does happiness lead to success? Psychological Bulletin, 131(6), 803-855.

Lyubomirsky, S., Sheldon, K. M., \& Schkade, D. (2005b). Pursuing happiness: The architecture of sustainable change. Review of General Psychology, 9(2), 111-131.

Mansfield, C. F., Beltman, S., Broadley, T., \& Weatherby-Fell, N. (2016). Building resilience in teacher education: An evidenced informed framework. Teaching and Teacher Education, 54, 77-87.

Maslach, C., Jackson, S. E., \& Leiter, M. P. (1996). Maslach burnout inventory. Palo Alto, CA: Consulting Psychologists Press.

McCallum, F., \& Price, D. (2010). Well teachers, well students. Journal of Student Wellbeing, 4(1), 19-34.

McCallum, F., \& Price, D. (2016). Teacher wellbeing. In F. McCallum \& D. Price (Eds.), Nurturing wellbeing development in education (pp. 113-132). London: Routledge.

McCullough, M. M. (2015). Improving elementary teachers' well-being through a strengths-based intervention: A multiple baseline single-case design. Graduate Theses and Dissertations. http://scholarcommons. usf.edu/etd/5990.

McKinney, D., Dyck, J. L., \& Luber, E. S. (2009). iTunes University and the classroom: Can podcasts replace professors? Computers \& Education, 52(3), 617-623.

Moè, A., Pazzaglia, F., \& Ronconi, L. (2010). When being able is not enough. The combined value of positive affect and self-efficacy for job satisfaction in teaching. Teaching and Teacher Education, 26(5), 11451153.

Pluut, H., Curșeu, P. L., \& Ilies, R. (2015). Social and study related stressors and resources among university entrants: Effects on well-being and academic performance. Learning and Individual Differences, 37, 262268.

Popovaa, A., \& Edirisingha, P. (2010). How can podcasts support engaging students in learning activities? Procedia Social and Behavioral Sciences, 2(2), 5034-5038.

Rahm, T., \& Heise, E. (2019). Teaching happiness to teachers - development and evaluation of a training in subjective well-being. Frontiers in Psychology. https://doi.org/10.3389/fpsyg.2019.02703.

Schoeps, K., de la Barrera, U., \& Montoya-Castilla, I. (2019). Impact of emotional development intervention program on subjective well-being of university students. Higher Education, 79, 711-729. https://doi.org/ 10.1007/s10734-019-00433-0.

Schueller, S. M. (2014). Person-activity fit in positive psychological interventions. In A. C. Parks \& S. M. Schueller (Eds.), The Wiley-Blackwell handbook of positive psychological interventions (pp. 385-402). Hoboken: Wiley Blackwell.

Schüle, C., Schriek, J., Kahlert, D., \& Arnold, K.-H. (2017). Die Beanspruchungsregulation von Lehramtsstudierenden im Praxissemester. [Student teachers' strain regulation during their student teaching semester]. Lehrerbildung auf dem Prüfstand, [Teacher education under review], 10(1), 94-106.

Seligman, L., \& Adler, A. (2019). Positive education. In J. F. Helliwell, R. Layard, \& J. Sachs (Eds.), Global happiness and wellbeing policy report 2019 (pp. 53-72). New York: Global Happiness Council.

Seligman, M. E. P., Steen, T. A., Park, N., \& Peterson, C. (2005). Positive psychology progress: Empirical validation of interventions. American Psychologist, 60(5), 410-421.

Sharp, J., \& Theiler, S. (2018). A review of psychological distress among university students: Pervasiveness, implications and potential points of intervention. International Journal for the Advancement of Counselling, 40(3), 193-212.

Slemp, G. R., Chin, T.-C., Kern, M. L., Siokou, C., Loton, D., Oades, L. G., Vella-Brodrick, D., \& Waters, L. (2017). Positive education in Australia: Practice, measurement, and future directions. In E. Frydenberg, A. J. Martin, \& R. J. Collie (Eds.), Social and emotional learning in Australia and the Asia-Pacific: Perspectives, programs and approaches (pp. 101-122). Singapore: Springer.

Smith, E. R., \& Avetisian, V. (2011). Learning to teach with two mentors: Revisiting the 'two-worlds pitfall' in student teaching. The Teacher Educator, 46(4), 335-354. 
Smith, J. L., Harrison, P. R., Kurtz, J. L., \& Bryant, F. B. (2014). Nurturing the capacity to savor: Interventions to enhance the enjoyment of positive experiences. In A. C. Parks \& S. M. Schueller (Eds.), The Wiley Blackwell handbook of positive psychological interventions (pp. 42-65). Chichester: Wiley Blackwell.

Squires, V. (2019). The well-being of the early career teacher: A review of the literature on the pivotal role of mentoring. International Journal of Mentoring and Coaching in Education, 8(4), 255-267.

Stallman, H. M., Ohan, J. L., \& Chiera, B. (2018). The role of social support, being present and self-kindness in university student well-being. British Journal of Guidance \& Counselling, 46(4), 365-374.

Stanton, A., Zandvliet, D., Dhaliwal, R., \& Black, T. (2016). Understanding students' experiences of wellbeing in learning environments. Higher Education Studies, 6(3), 90-99.

Sutton, R. E., \& Wheatley, K. F. (2003). Teachers' emotions and teaching: A review of the literature and directions for future. Educational Psychology Review, 15(4), 327-358.

Thomas, K., \& Bendtsen, M. (2019). Mental health promotion among university students using text messaging: Protocol for a randomized controlled trial of a mobile phone-based intervention. JMIR Research Protocols, 8(8), e12396-e12396. https://doi.org/10.2196/12396.

VanderWeele, T. J. (2019). Measures of community well-being: A template. International Journal of Community Well-Being, 2(3), 253-275.

Viac, C., \& Fraser, P. (2020). Teachers well-being: A framework for data collection and analysis. Paris: OECD Education Working Paper No. 213.

Wallace, C., \& Vincent, K. (2017). Community well-being and information technology. In R. Phillips \& C. Wong (Eds.), Handbook of community well-being research (pp. 169-188). Dordrecht: Springer.

Waters, L., \& Loton, D. (2019). SEARCH: A meta-framework and review of the field of positive education. International Journal of Applied Positive Psychology, 4(1), 1-46.

White, B., \& Cornu, R. L. (2002). Email reducing stress for student teachers. In D. Watson \& J. Andersen (Eds.), Networking the learner: Computers in education (pp. 671-679). Boston: Springer.

Wilcox, G., \& Nordstokke, D. W. (2019). Predictors of university student satisfaction with life, academic selfefficacy, and achievement in the first year. Canadian Journal of Higher Education, 49(1), 104-124.

Yelderen, S., Durksen, T. L., \& Klassen, R. M. (2018). An international validation of the engaged teachers scale. Teachers and Teaching, 24(6), 673-689.

Zeichner, K. (2010). Rethinking the connections between campus courses and field experiences in collegeand university-based teacher education. Journal of Teacher Education, 61(1-2), 89-99.

Publisher's Note Springer Nature remains neutral with regard to jurisdictional claims in published maps and institutional affiliations. 